\title{
Another Look at the Urbankte Site (41CV26) in Coryell County, Texas
}

Timothy K. Perttula

Heritage Research Center, Stephen F. Austin State University

Harry J. Shafer

Follow this and additional works at: https://scholarworks.sfasu.edu/ita

Part of the American Material Culture Commons, Archaeological Anthropology Commons, Environmental Studies Commons, Other American Studies Commons, Other Arts and Humanities Commons, Other History of Art, Architecture, and Archaeology Commons, and the United States History Commons

Tell us how this article helped you.

This Article is brought to you for free and open access by the Center for Regional Heritage Research at SFA ScholarWorks. It has been accepted for inclusion in Index of Texas Archaeology: Open Access Gray Literature from the Lone Star State by an authorized editor of SFA ScholarWorks. For more information, please contact cdsscholarworks@sfasu.edu. 


\section{Another Look at the Urbankte Site (41CV26) in Coryell County, Texas \\ Creative Commons License \\ (c) $($ ) $(9)$}

This work is licensed under a Creative Commons Attribution-NonCommercial 4.0 International License 


\title{
Another Look at the Urbankte Site (41CV26) in Coryell County, Texas
}

\author{
Timothy K. Perttula and Harry J. Shafer
}

\section{Introduction}

Perttula (2016) had analyzed ceramic sherds and other material culture remains curated at the Texas Archeological Research Laboratory at The University of Texas at Austin (TARL) from four sites in the Brazos River basin in the Central Texas prairie that had been identified as Prairie Caddo sites by Shafer (2006; see also Shafer 2013:48); one of the sites was the Urbankte site (41CV26). The Urbankte site is on the Leon River in Coryell County, at Belton Reservoir; the Leon River is a southward-flowing tributary to the Brazos River (Miller and Jelks 1952) (Figure 1). The term "Prairie Caddo" used by Shafer refers to Caddo groups affiliated with Caddo communities in East Texas, most likely affiliated with the George C. Davis site in the Neches River valley, that occupied portions of the Central Texas prairies in Late Prehistoric times, from ca. A.D. $1000-1300$.

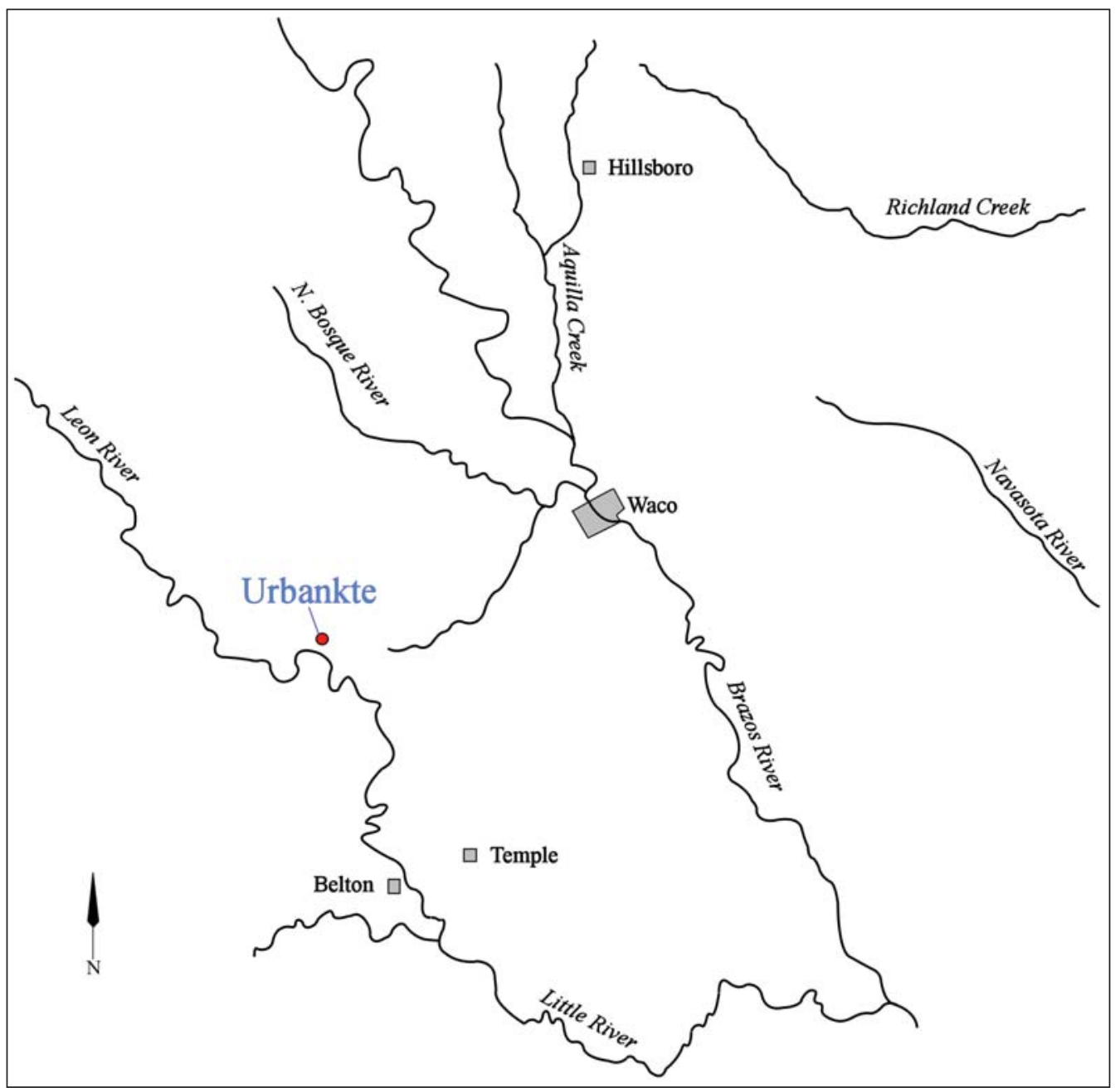

Figure 1. The location of the Urbankte site in the Brazos River basin of Central Texas. 
Each of the four assemblages in the Brazos River basin have sherds that stylistically compare closely to decorated Caddo vessels from East Texas Caddo sites, and the distinctive character of these decorated sherds suggested that the four sites were occupied between ca. A.D. 1000-1200 or to post-ca. A.D. 1200-1300 times in the case of the Urbankte site. Where these ceramic assemblages seemed to differ from East Texas Caddo ceramics, however, was in their manufacture: the grog and bone temper inclusions added to the paste of the ceramic vessel sherds from these sites had numerous, large, and coarse-grained temper inclusions, while East Texas Caddo ceramics tend to have more fine-grained temper inclusions, even in the manufacture of utility ware jars (cf. Perttula 2013).

The Urbankte site ceramics ( $\mathrm{n}=118$ sherds) I examined at TARL were heavily bone-tempered ( 88 percent) and had a considerable proportion of brushed sherds (46 percent of the decorated sherds) (Perttula 2016). Both characteristics were consistent with a post A.D. 1200-1300 Prairie Caddo occupation, as was the fact that eight of the nine arrow points in the TARL collections from the Urbankte site are Perdiz arrow points. The common occurrence of both Perdiz points and brushed ceramic sherds (see Perttula 2013) suggested then that this Prairie Caddo occupation at the Urbankte site took place sometime after ca. A.D. 1200-1300.

As Dr. Shafer mentions below, the artifacts from the Urbankte site that he had discussed in the Prairie Caddo module (Shafer 2006) were from a different part of the site than the TARL collection I had documented (Perttula 2015), and were from a different and earlier cultural component. We will return to those artifacts shortly.

\section{Memories of the Site, by Harry J. Shafer}

The collection that is at TARL from the Urbankte site may be from the plowed field north of the mouth of Horse Creek. The collection that I made as a teenager came from the north side of the bank of Horse Creek; the cultural deposits were buried at a level of about $30-40 \mathrm{~cm}$ bs and the assemblage contained Pennington Punctated-Incised sherds, Davis Incised sherds, Bonham-Alba arrow points, and a Gahagan knife (see below). The Urbanke field had at least two geographically separate components. The one in the field also had Perdiz arrow points whereas the component in the creek bank had Bonham-Alba points and one Scallorn arrow point. It is the creek bank component that I used in the Prairie Caddo module (Shafer 2006).

\section{Early Caddo Period Ceramic and Lithic Artifacts from the Urbankte Site}

The ceramic sherds from the earlier Prairie Caddo component at the Urbankte site are from a ca. A.D. 900-1200 occupation. The principal decorated rim and body sherds are from Pennington Punctated-Incised vessels with zoned incised diagonals and triangular elements filled with triangular-shaped tool punctations (Figure 2). There are also likely body sherds from contemporaneous Davis Incised and Dunkin Incised vessels (see Suhm and Jelks 1962) in the collection.

Chipped stone tools found in this component at the Urbankte site include several Bonham-Alba (cf. Shafer 2006) arrow points made from Central Texas cherts (Figure 3). There is also a well-made Gahagan biface in this collection (Figure 4), also made from local Central Texas chert. Both types of chipped stone tools occur in Early Caddo period contexts in Prairie Caddo sites in the Central Texas prairie.

\section{Summary and Conclusions}

The Urbankte site was evidently occupied by Prairie Caddo groups on at least two occasions, one between ca. A.D. 900-1200 (contemporaneous with the Early Caddo period in East Texas) and the other sometime after ca. A.D. 1200-1300, contemporaneous with either the Middle or Late Caddo periods in East Texas. The earlier of the two components had early Caddo period ceramic sherds from Pennington Punctated-Incised and Davis Incised vessels, Bonham-Alba arrow points, and a Gahagan biface. The later component at the Urbankte site was characterized by numerous Perdiz arrow points, many bone-tempered ceramic vessels, and a considerable proportion of brushed sherds from utility ware vessels. 


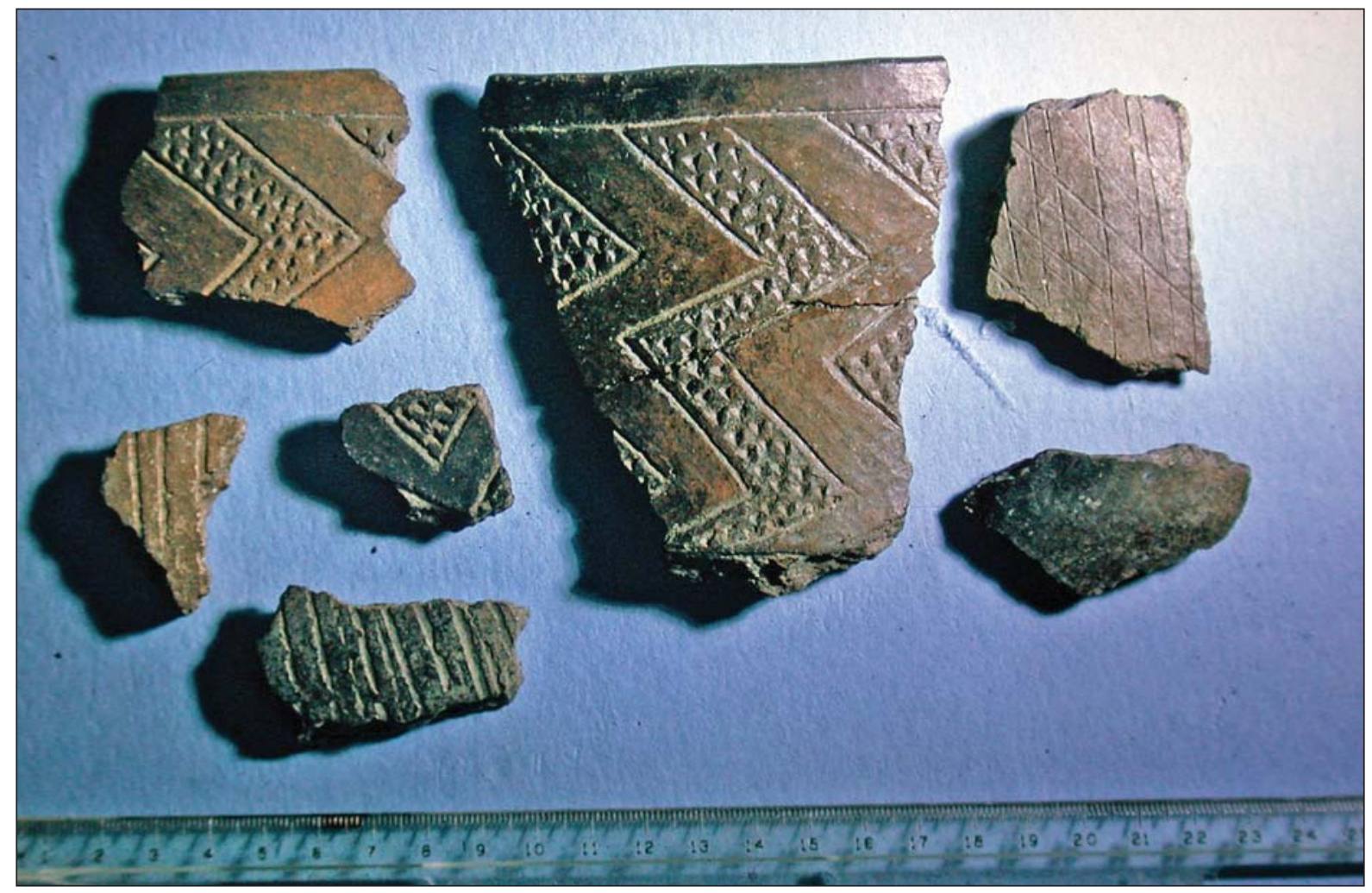

Figure 2. Early Caddo period ceramic sherds from the Urbankte site.

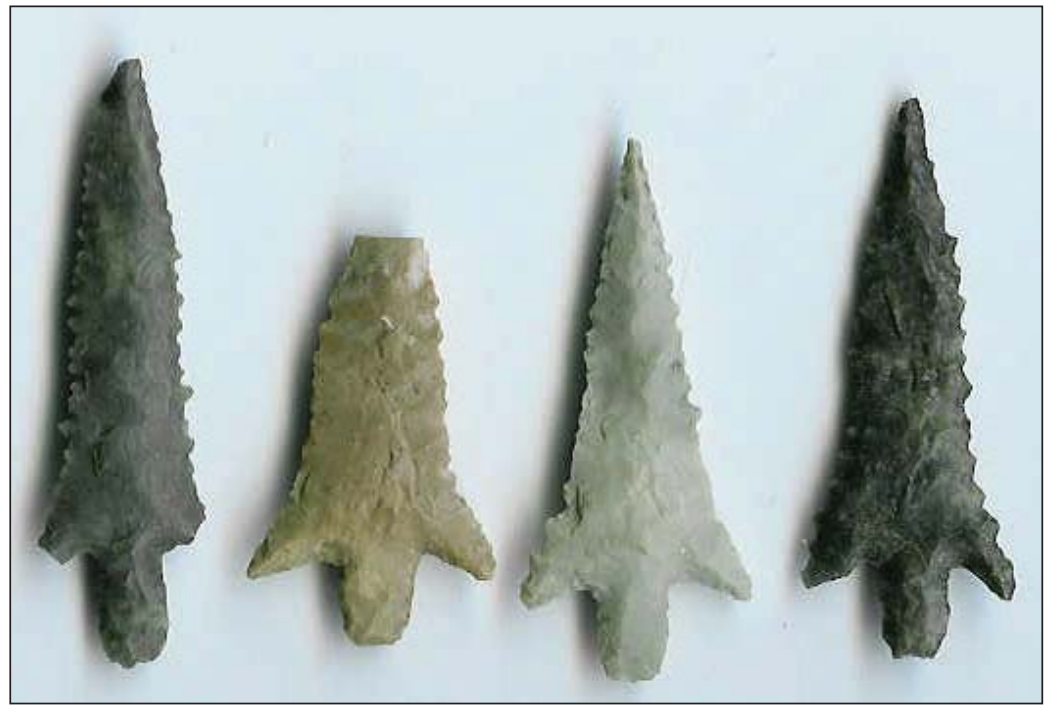

Figure 3. Bonham-Alba arrow points from the Urbankte site.

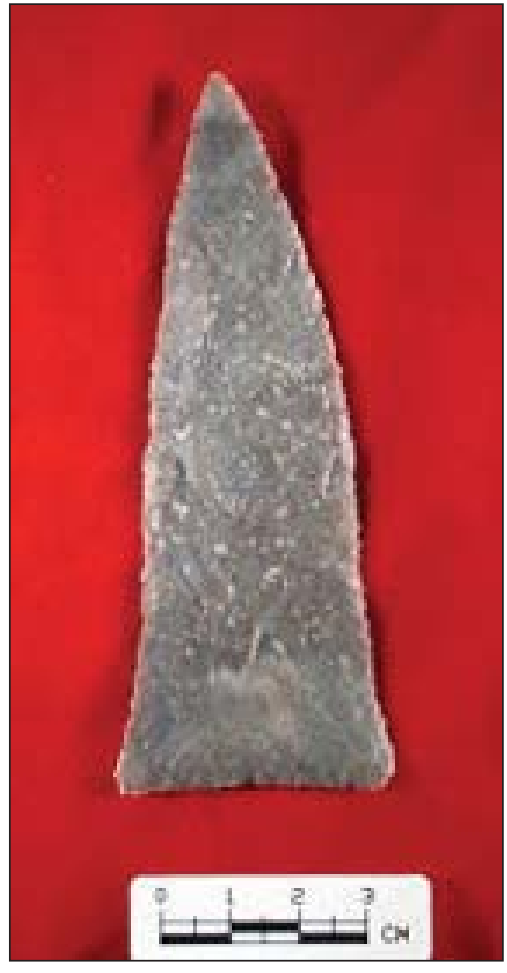

Figure 4. Gahagan biface from the Urbankte site. 


\section{Acknowledgements}

Lance Trask prepared Figure 1 for this article. The artifact photographs have been provided by Dr. Shafer.

\section{References Cited}

Miller, E. O. and E. B. Jelks

1952 Archeological Investigations at the Belton Reservoir, Coryell County, Texas. Bulletin of the Texas Archeological and Paleontological Society 23:168-217.

Perttula, T. K.

2013 Caddo Ceramics in East Texas. Bulletin of the Texas Archeological Society 84:181-212.

2016 Prairie Caddo Sites in Coryell and McLennan Counties in Central Texas. Journal of Northeast Texas Archaeology 58:41-66.

Shafer, H. J.

2006 People of the Prairie: A Possible Connection to the Davis Site Caddo. Texas Department of Transportation and Prewitt and Associates, Inc., Austin.

2013 Miscellaneous Notes and Remembrances: Starting an Archaeological Career in Central Texas. La Tierra 39:39-52.

Suhm, D. A. and E. B. Jelks (editors)

1962 Handbook of Texas Archeology: Type Descriptions. Special Publication No. 1, Texas Archeological Society, and Bulletin No. 4, Texas Memorial Museum, Austin. Reprinted in 2009, Gustav's Library, Davenport, Iowa. 